\title{
EFFECT OF ACTIVE IMMUNIZATION AGAINST GROWTH HORMONE RELEASING FACTOR ON CONCENTRATIONS OF SOMATOTROPIN AND INSULIN-LIKE GROWTH FACTOR I IN LACTATING BEEF COWS
}

\author{
K.L. Moore , J.D. Armstrong", R.W. Harvey, \\ R.M. Campbell and E. P. Heimer
}

\begin{abstract}
Two experiments were conducted to determine the effects of immunoneutralization of growth hormone-releasing factor [GRF(1-29)- $\mathrm{NH}_{2}$ ] on concentrations of somatotropin (ST) and insulin-like growth factor I (IGF-I) in lactating beef cows. In Experiment 1, multiparous Hereford cows were immunized against $2 \mathrm{mg} \mathrm{GRF}(1-29)-(\mathrm{Gly})_{4}-\mathrm{Cys}-\mathrm{NH}_{2}$ conjugated to human serum albumin (GRFi, $\mathrm{n}=3$ ) or $2 \mathrm{mg}$ human serum albumin (HSAi, $\mathrm{n}=3$ ) at $52 \pm 1 \mathrm{~d}$ prior to parturition. Boosters ( $1 \mathrm{mg}$ ) were administered on days 12, 40 and 114 postpartum (pp). Serum samples were collected at 15-min intervals for $5 \mathrm{hr}$ on days 18,46 and $120 \mathrm{pp}$, followed by administration (IV) of an opioid agonist (FK33-824; $10 \mu \mathrm{g} / \mathrm{kg}$ ) and an antagonist (naloxone; $5 \mathrm{mg} / \mathrm{kg}$ ) at hours 5 and 7 , respectively. A GRFanalog ([desamino-Tyr $\left.{ }^{1}, \mathrm{D}-\mathrm{Ala}^{2}, \mathrm{Ala}^{15}\right] \mathrm{GRF}(1-29)-\mathrm{NH}_{2} ; 3.5 \mu \mathrm{g} / \mathrm{kg}$ ) and arginine $(.5 \mathrm{~g} / \mathrm{kg}$ ) were administered at hour 10 on days 47 and 121, respectively. Percentage binding of [ ${ }^{125}$ I]GRF (1:100 dilution of serum) $28 \mathrm{~d}$ after primary immunization was greater in GRFi (14.3 \pm 4.9$)$ than in HSAi $(.7 \pm .3)$ cows. Binding increased to $29.3 \pm 6.5 \%$ after first booster in GRFi cows. Episodic release of ST was abolished by immunization against GRF; concentration and frequency of release of ST were lower $(\mathbf{P}<.05)$ in GRFi than in HSAi cows on all days pp. Concentrations of IGF-I were lower in GRFi than in HSAi cows throughout lactation. Serum ST failed to increase following FK33-824 or arginine in GRFi; however, ST increased after both compounds in HSAi cows. Concentrations of ST following GRF-analog were greater $(\mathrm{P}<.05)$ in HSAi than in GRFi cows. Experiment 2 was conducted to determine if a lower dose of antigen and a single booster would be sufficient to lower ST and IGF-I in lactating cows. Multiparous Hereford and Angus cows were assigned to GRFi $(n=6)$ or HSAi $(\mathrm{n}=6)$. Primary $(1.2 \mathrm{mg})$ and booster $(.5 \mathrm{mg})$ immunizations were administered -14 and 8 $\mathrm{d}$ from calving, respectively. Cows were restricted to $60 \%$ of recommended intake of energy during lactation in order to elevate concentrations of ST. Serum samples were collected at 15-min intervals for $6 \mathrm{hr}$ on days 26, 50,73,90 and $109 \mathrm{pp}$. Two of six GRFi cows had binding less than $10 \%$ (1:1,000 dilution of serum) and were omitted from further analyses. Percentage binding at a 1:1,000 dilution was greater in GRFi $(17.0 \pm 4.7)$ than in HSAi $(1.4 \pm .4)$ cows at $89 \mathrm{~d}$ pp. Consequently, frequency of release, and concentration of ST and IGF-I were lower $(P<.05)$ in GRFi than in HSAi cows. Concentrations of ST increased following FK33-824 in HSAi, but not in GRFi cows. Across experiments, interval from calving to ovulation (estimated from weekly progesterone concentrations) was greater in HSAi than in GRFi cows. In conclusion, gestating-lactating beef cows were effectively immunized against GRF as evidenced by antibody binding of [ $\left.{ }^{125} I\right] G R F$, absence of pulsatile release of ST, low concentrations of ST and IGF-I and failure of ST to increase after IV opioid agonist or arginine.
\end{abstract}




\section{INTRODUCTION}

Somatotropin (ST) plays an important role in regulating metabolic changes necessary for growth $(1,2)$ and lactation (3). Exogenous ST enhances retention of nitrogen (4), increases body weight gain in growing ruminants (1) and increases milk yield in dairy cows (3). During lactation in the pig and cow, suckling causes an increase in circulating prolactin and ST and a decrease in luteinizing hormone ( $\mathrm{LH}, 5-9)$.

Release of ST is regulated by a dual system of hypothalamic peptides in which growth hormone-releasing factor (GRF) stimulates (10-11) and somatostatin inhibits (12) release of ST. In the pig, suckling increases ST (7) and decreases LH (5-6) through an increase in endogenous opioid peptides mediated by the hypothalamus. Opioid agonists cause an increase in ST and a decrease in LH in non-lactating ruminants (13-14), whereas naloxone, an opioid antagonist, increased serum LH in lactating cows (9). A paucity of information exists concerning factors controlling ST release during lactation in the beef cow.

Previously, we demonstrated that active immunization against growth hormone releasing factor [GRF-(1-29)-(Gly) $\left.)_{4}-\mathrm{Cys}-\mathrm{NH}_{2}\right]$ abolished episodic release of ST and decreased serum insulin-like growth factor I (IGF-I) in cycling gilts (15) and prepubertal heifers (16). We reasoned that this approach would provide an excellent model for evaluating control of ST during lactation as well as provide a model for future investigation of the interaction between metabolism and reproduction in the postpartum beef cow. The objective of this experiment was to determine whether gestating-lactating beef cows could be actively immunized against GRF and to determine the effects of immunization on concentrations of ST and IGF-I. In addition, we tested the hypothesis that an opioid agonist would increase ST in control, but not in GRF-immunized cows (15), whereas we hypothesized that naloxone would decrease ST in both GRF-immunized and control cows as previously reported for lactating sows (7).

\section{MATERIALS AND METHODS}

Experiment 1: Six multiparous Hereford cows $(523 \pm 23 \mathrm{~kg})$ were used to determine whether beef cows could be actively immunized against GRF and to determine the effect of immunoneutralization of GRF on concentrations of ST and IGF-I. Cows were randomly assigned to be immunized against GRF conjugated to human serum albumin $(n=3)$ or human serum albumin alone $(n=3)$. Primary immunization was administered $52 \pm 1 \mathrm{~d}$ prepartum by injecting $2 \mathrm{mg} \mathrm{GRF}$ analog [GRF(1-29)-(Gly) ${ }_{4}-\mathrm{Cys}-\mathrm{NH}_{2}$ ] conjugated to $2 \mathrm{mg}$ human serum albumin (GRFi) or $2 \mathrm{mg}$ human serum albumin (HSAi) emulsified in Freund's complete adjuvant. The antigen used was developed for conjugation at the carboxyl terminus of human serum albumin. Conjugation was performed using the m-maleimido benzoyl-N-hydroxysuccinimide procedure (17). Boosters of appropriate antigen ( $1 \mathrm{mg}$ ) emulsified in Freund's incomplete adjuvant were administered on days $12 \pm 1,40 \pm 1$, and $114 \pm 1$ postpartum (pp). Blood samples were collected via venipuncture at the time of booster and one week later for determination of antibody production. Immunizations and subsequent boosters were emulsified in a 1:1 ratio with Freund's complete or incomplete adjuvant (Sigma Chemical Co., St. Louis, MO), respectively, and administered as 4 to 5 subcutaneous injections dorsal to the udder.

During gestation, cows were allowed free access to fescue pasture and supplemented with trace mineral salt blocks. During lactation, cows were fed alfalfa hay free choice.

Body weight was recorded every 2 wks and blood samples were collected at weekly intervals during lactation. Samples were analyzed for GRF antibody and progesterone concentrations. Onset of ovulation was estimated to occur when progesterone concentrations greater than $1 \mathrm{ng} / \mathrm{ml}$ were sustained for $2 \mathrm{wks}$.

During lactation, milk consumption by calves $(\mathrm{kg} / \mathrm{d})$ was estimated by weigh-suckle-weigh beginning on day $86 \mathrm{pp}$ and continuing at 1 to $2 \mathrm{wk}$ intervals until day $137 \mathrm{pp}$. Calves were 
separated from their dams for $8 \mathrm{hr}$, weighed, allowed to nurse and weighed again. The difference in body weight (BW) was multiplied by 3 to estimate daily consumption.

On days 18,46 and $120 \mathrm{pp}$ ( 1 week after each booster) cows were non-surgically cannulated by inserting a cannula into the jugular vein through a 12 gauge needle and securing the cannula to the skin with elastic tape. The next day, blood samples were collected every 15 minutes for a period of $9,13.5$ and $14 \mathrm{hr}$ on days 19,47 and 121 , respectively. Calves were allowed to nurse during the sampling intervals. Samples obtained over the first $5 \mathrm{hr}$ were used for determination of concentrations of ST. An opioid agonist [(D$\mathrm{Ala}^{2}, \mathrm{MePhe}^{4}, \mathrm{Met}(\mathrm{O})^{5}$-ol)-enkephalin, FK33-824;10 $\mathrm{gg} / \mathrm{kg} ; 181$ and an antagonist (naloxone; $.5 \mathrm{mg} / \mathrm{kg}$ ) were administered (IV) at $\mathrm{hr} 5$ and 7, respectively. Efficacy of immunization against GRF was further tested by administration of a GRF-analog ([desamino$\left.\mathrm{Tyr}^{1}, \mathrm{D}-\mathrm{Ala}^{2}, \mathrm{Ala}^{15}\right]$ GRF (1-29) $\left.\mathrm{NH}_{2} ; 3.5 \mu \mathrm{g} / \mathrm{kg} ; 19,20\right)$ (IV) on day 47 at hr 10 and injection (IV) of arginine $(.5 \mathrm{~g} / \mathrm{kg})$ at hr 10 on day 121 .

Blood samples were stored at $4 \mathrm{C}$ for approximately $18 \mathrm{hr}$, centrifuged at $1,500 \mathrm{~g}$ for 30 minutes and serum decanted and stored at $-20 \mathrm{C}$ until assayed. All samples were analyzed for ST, and samples collected pre- and post-naloxone (on days 19 and 47 only) were analyzed for LH. Selected samples ( $3 \mathrm{hr}$ intervals) were analyzed for IGF-I.

Experiment 2: Based on results in Experiment 1, a second experiment was conducted to determine if a lower dose of antigen and a single booster would produce similar effects on ST and IGF-I. Gestating multiparous Hereford and Angus cows (581 $\pm 30 \mathrm{~kg}$ ) were randomly assigned to GRFi $(n=6)$ or HSAi $(n=6)$. Primary $(1.2 \mathrm{mg})$ and booster $(.5 \mathrm{mg}) \mathrm{im}-$ munizations were administered as described in Experiment 1, approximately -14 and $8 \mathrm{~d}$ postpartum, respectively.

Within 1 week after parturition, both cow and calf were moved to an open-sided barn and placed in a pen $(4 \times 7 \mathrm{~m})$ equipped with 12 calan gates. Two calves were born dead; Holstein calves were substituted within $24 \mathrm{hr}$ after calving.

Cows were restricted in intake of energy during lactation in order to elevate concentrations of ST, because restriction of feed intake increases concentrations of ST in ruminants (21). The diet was formulated to provide $60 \%$ of recommended energy intake while keeping crude protein, calcium, phosphorus and vitamin $\mathrm{A}$ at $100 \%$ of NRC requirements (22).

On days $26,50,73,90$ and $109 \mathrm{pp}(\mathrm{SE}=.3)$ blood samples were collected at $15-\mathrm{min}$ intervals for $6 \mathrm{hr}$ from all cows to quantify concentrations of ST and IGF-I. On days 27, 51, 91 and 110 , HSAi $(n=3)$ and GRFi $(n=4)$ cows were given naloxone and subsequently FK33-824. Samples were collected at 15-min intervals for $6.5 \mathrm{hr}$. Naloxone was administered (IV) at a dose of $.5 \mathrm{mg} / \mathrm{kg}$ at 30 and $90 \mathrm{~min}$, since in Exp. 1 a single injection of naloxone failed to decrease serum ST. At $270 \mathrm{~min}$, cows were administered FK33-824 (10 $\mu \mathrm{g} / \mathrm{kg}$ ). Cannulation, blood sampling and processing procedures were similar to that described in Experiment 1. Calves were not allowed to nurse during sampling.

Milk consumption by calves and onset of ovulation were determined as described for Exp. 1. Milk consumption was estimated every 2 wks from days 64 to $110 \mathrm{pp}$.

In both Experiments, cows were acclimated to halters during gestation. Cows were observed for signs of distress during each sampling interval. Throughout Experiment 1, signs of distress were not noted and cows remained haltered throughout each sampling interval. On days 26, 27, 50 and 51 of Exp. 2, both GRFi and HSAi cows were restless and pulled against their halter throughout the sampling interval. Consequently, samples were collected on days 73, 90, 91, 109 and 110 from cows while housed in individually-partitioned, stationary alleys $(1.8 \times .7 \mathrm{~m})$. Visible signs of distress were not observed in this environment. Single samples were analyzed for cortisol on days 26, 50, 73, 90, and 109 in Experiment 2 , only.

Assays: Antibody binding against GRF was determined by incubating diluted serum ( $1: 100$ to $1: 16,000$ ) with ${ }^{125}$ I-GRF as described by Armstrong et al (15). Binding at 50\% 
was not achieved at any dilution; therefore, antibody concentration was expressed as percentage bound at a 1:100 and 1:1,000 dilution in Experiments 1 and 2, respectively.

Serum ST was measured by radioimmunoassay procedures validated by Armstrong and Spears (23). For Experiment 1, intra- and inter-assay CV for 3 assays were $9.5 \%$ and $13.0 \%$, respectively. Assay sensitivity, defined as $90 \%$ bound, was $1.5 \mathrm{ng} / \mathrm{ml}$. Intra- and inter-assay CV for 8 assays for Experiment 2 were $7.9 \%$ and $13.0 \%$, respectively; assay sensitivity was $0.6 \mathrm{ng} / \mathrm{ml}$.

Concentrations of LH were estimated as previously described $(23,24)$. Intra- and interassay CV for 3 assays in Experiment 1 were $7.4 \%$ and $14.6 \%$, respectively. Assay sensitivity was $.4 \mathrm{ng} / \mathrm{ml}$.

Serum IGF-I was assayed using glycylglycine hydrochloride extraction procedures as described (25) with modifications $(26,27)$. The standard source was recombinant human IGF-I (Amgen, Thousand Oaks, CA). Anti-IGF-I rabbit serum (UBK487) was obtained from Drs. L. Underwood and J. Van Wyk (Univ. North Carolina, Chapel Hill, NC) through the National Hormone and Pituitary Program and the NIDDK. Average intra-assay coefficient of variation was $6.3 \%$ for Experiment 1 and $2.8 \%$ for Experiment 2 . Assay sensitivity, defined as $90 \%$ bound was $9.0 \mathrm{ng} / \mathrm{ml}$.

Progesterone and cortisol were determined by a solid-phase radioimmunoassay (Diagnostic Products Corp., Los Angeles, CA). Assay sensitivity was $0.1 \mathrm{ng} / \mathrm{ml}$ and $3.3 \mathrm{ng} / \mathrm{ml}$ for progesterone and cortisol, respectively. Progesterone intra-assay CV for experiment 1 and 2 was $7.9 \%$ and $7.2 \%$, respectively. Cortisol intra-assay CV for Experiment 2 was $1.8 \%$.

Statistical Analyses: All analyses were performed using general linear models procedures (28). Hormone data were analyzed using a model consisting of treatment, cow within treatment, day, treatment $\times$ day, day $\times$ cow within treatment, time, time $\times$ treatment, time $\times$ treatment $\times$ day. The effect of treatment was tested using the cow within treatment mean square as the error term. Effects of day and treatment $\times$ day were tested using the day $\times$ cow within treatment mean square as the error term. For days from calving to elevated progesterone only, Exp. 1 and 2 were combined. The model included treatment, experiment and experiment $\mathrm{x}$ treatment.

Episodes of ST release were identified as samples greater than the mean plus one standard deviation for that sample period; the amplitude of the peak (concentration of the peak minus the concentration of the preceding nadir) had to be greater than the assay sensitivity and the peak concentration had to be at least $50 \%$ greater than the previous nadir. Basal ST was determined as average ST after episodes of ST were deleted.

\section{RESULTS}

Experiment 1: Antibody binding against GRF, expressed as percentage binding at 1:100 dilution, for GRFi and HSAi cows is presented in Figure 1. Within $28 \mathrm{~d}$ after primary immunization, binding increased $(P<.01)$ in GRFi cows from $<2$ to $14.3 \pm 4.9 \%$, while binding in HSAi cows was low $(0.7 \pm 0.3 \%)$ throughout the experiment. Percentage binding increased $(P<.01)$ in GRFi cows after the first booster, but did not increase $(P>.50)$ after the second and third booster.

Mean ST concentrations on days 19,47 , and 121 pp were lower $(P<.05)$ in GRFi than in HSAi cows (Table 1). Pulsatile release of ST was abolished $(P<.01$ ) in GRFi cows on all days postpartum. A treatment $x$ day interaction was detected for basal ST due to ST being lower in GRFi than in HSAi cows on day 47, but not on days 19 and 121 (Table 1).

Concentrations of IGF-I were lower $(P<.05)$ in GRFi than in HSAi cows on days 19 , 47 and $121 \mathrm{pp}$ (Figure 2). In HSAi cows only, serum IGF-I concentrations were greater ( $\mathrm{P}$ $<.05$ ) on days 19 and $47 \mathrm{pp}$ than on day $121 \mathrm{pp}$.

Concentrations of ST failed to increase after administration of FK33-824 in GRFi cows on days 19,47 or $121 \mathrm{pp}$ (Figure 3). On day 19, concentrations of ST in HSAi cows failed 


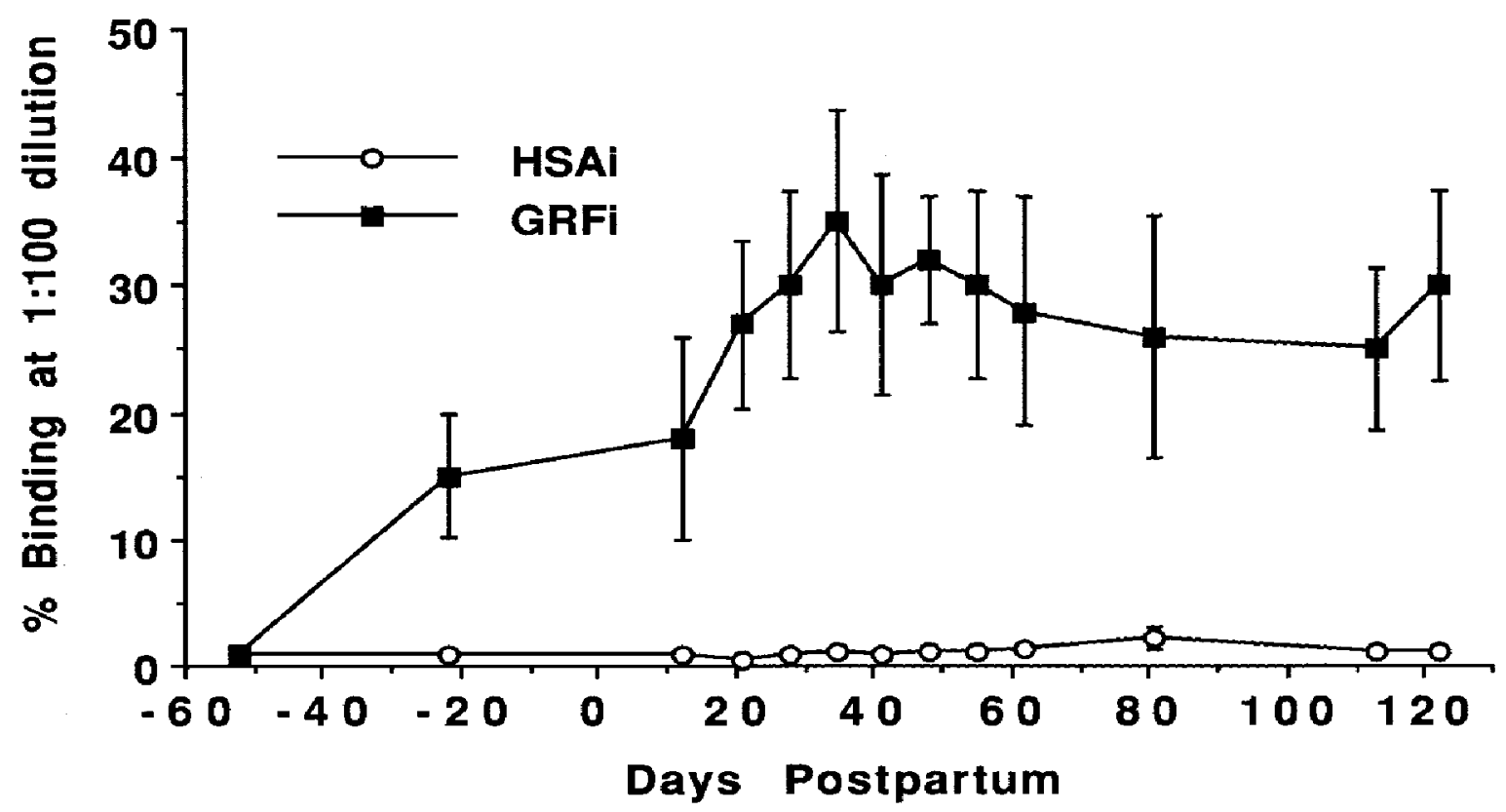

Figure 1. Mean ( \pm SE) percentage binding of $\left.{ }^{125} I\right) G R F(1-29) \mathrm{NH}_{2}$ at a 1:100 dilution of serum from cows immunized against GRF conjugated to HSA (GRFi) or HSA alone (HSAi). Primary immunization was given on day -52 from calving. Booster doses were injected on days 12, 40 and 114 postpartum (Exp. 1).

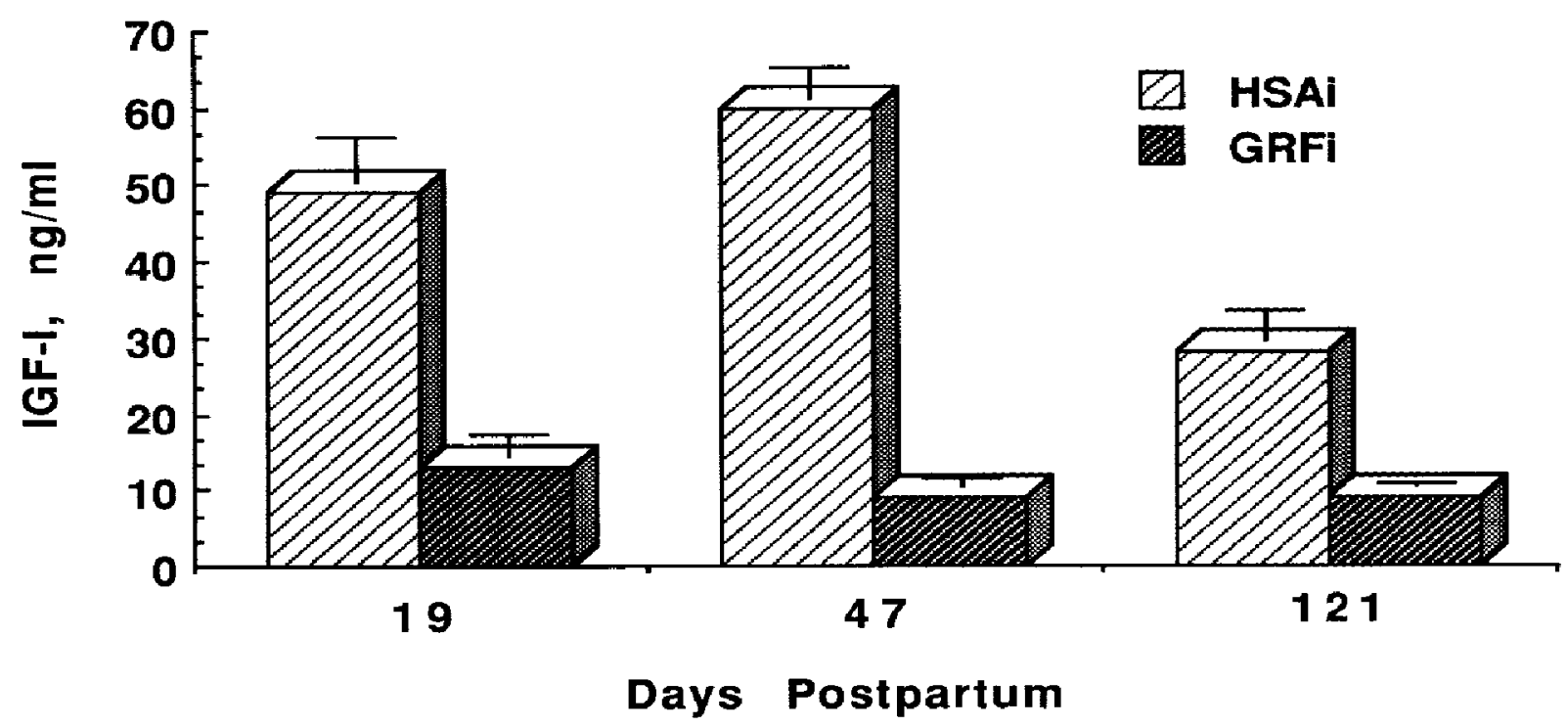

Figure 2. Mean \pm SE concentrations of IGF-I on days 19,47 and 121 postpartum in GRFi and HSAi cows. Serum IGF-I concentrations were lower $(P<0.05)$ in GRFi than in HSAi cows on all days postpartum. Days postpartum affected IGF-I in HSAi $(\mathrm{P}<0.05)$, but not in GRFi cows (Exp. 1).

Table 1. Effect of Immunization Against GRF conjugated to HSA (GRFi) or HSA alone (HSAi) on Frequency of Release and Concentrations of Somatotropin (ST) (ExP. 1).

\begin{tabular}{|c|c|c|c|c|c|c|}
\hline & \multicolumn{2}{|c|}{ Mean ST (ng/ml) } & \multicolumn{2}{|c|}{$\begin{array}{l}\text { Episodic ST } \\
\text { (peaks } / 5 \mathrm{hr} \text { ) }\end{array}$} & \multicolumn{2}{|c|}{ Basal ST (ng/ml) } \\
\hline & HSAi & GRFi & HSAi & GRFi & HSAi & GRFi \\
\hline 19 & $6.7 \pm 0.4^{\mathrm{a} . \mathrm{b}}$ & $4.4 \pm 0.1$ & $1.3 \pm 0.3^{b}$ & $0.0 \pm 0.0$ & $5.0 \pm 0.6^{c}$ & $4.4 \pm 0.2$ \\
\hline 47 & $11.0 \pm 1.1^{b}$ & $3.7 \pm 0.1$ & $2.0 \pm 0.6^{b}$ & $0.0 \pm 0.0$ & $6.0 \pm 0.2$ & $3.7 \pm 0.3$ \\
\hline 121 & $8.6 \pm 0.7^{b}$ & $4.0 \pm 0.2$ & $2.0 \pm 0.6^{b}$ & $0.0 \pm 0.0$ & $4.3 \pm 0.2$ & $3.8 \pm 0.4$ \\
\hline
\end{tabular}

Mean \pm SE.

${ }^{b}$ HSAi different from GRFi cows, $\mathrm{P}<0.05$.

'Treatment by days postpartum, $\mathrm{P}<0.05$. 
to increase after FK33-824 (Figure 3, upper panel); however, on days 47 and 121 pp, concentrations of ST 60 minutes after FK33-824 were greater $(\mathrm{P}<.05)$ than concentrations prior to FK33-824 (Figure 3, middle and lower panel).

Concentrations of ST for both treatment groups were not affected $(P>.20)$ by naloxone on any sample day (data not presented). Naloxone increased $(\mathrm{P}<.05)$ concentrations of LH in HSAi and GRFi cows on day $47 \mathrm{pp}$; however, LH did not increase after naloxone on day 19 pp (Figure 4).

Administration of a GRF-analog on day 47 pp increased $(P<.01)$ concentrations of ST in both treatment groups when compared to concentrations prior to GRF-analog. Concentrations of ST at 15 minutes after GRF-analog were similar ( $>$ > .20, Figure 5) in GRFi and HSAi cows; however, concentrations of ST from 60 to 210 minutes were lower $(P<.01)$ in GRFi than in HSAi cows. Administration of arginine increased ST in HSAi, but not in GRFi cows. Average concentrations of ST (ng/ml) 30 to 90 minutes after arginine were greater $(P<.01)$ in HSAi than in GRFi cows (Figure 6).

Average milk consumption $(\mathrm{kg} / \mathrm{d})$ by calves on days 86 and 96 was greater $(\mathrm{P}<.05)$ in HSAi $(6.6 \pm .7)$ than in GRFi (3.2 \pm .5$)$ cows; however, consumption on days 115,131 and 137 was similar in HSAi (3.8 \pm .7$)$ and GRFi (3.2 \pm .7$)$ cows. In contrast, ADG of calves was not affected by treatment (data not presented).

Weight change $(\mathrm{kg})$ of cows from -52 to $74 \mathrm{~d}$ pp was lower $(\mathrm{P}<.05)$ in $\mathrm{HSAi}(-15 \pm 0.6)$ than in GRFi $(-4 \pm 4.9)$ cows. Interval from calving to elevated progesterone ( $>1 \mathrm{ng} / \mathrm{ml})$ tended $(\mathrm{P}=.12)$ to be greater in HSAi $(72 \pm 9 \mathrm{~d})$ than in GRFi $(53 \pm 0)$ cows.

Experiment 2: Two of six GRFi cows failed to respond to GRFi as evidenced by antibody binding ( $<10 \%$ at a 1:1,000 dilution of serum) and release of $\mathrm{ST}$ at a frequency similar to control cows. All data from these two cows were deleted from subsequent analyses.

Antibody binding to ${ }^{125} \mathrm{I}-\mathrm{GRF}(1-29) \mathrm{NH}_{2}$, expressed as percentage binding at 1:1,000 dilution, is presented in Table 2. At the time of primary immunization, percentage binding was very low in all cows; thereafter binding increased in GRFi but not in HSAi cows, particularly at $21 \mathrm{~d}$ after booster immunization (day $29 \mathrm{pp}$ ).

Concentrations of ST on days 26,50, 73, 90, and 109 pp are presented in Table 3. Concentrations of ST were lower $(\mathrm{P}<.05)$ in GRFi than in HSAi cows on all days postpartum. Mean ST in HSAi cows was greater on days 26 and 50 than on days 73, 90 and 109 pp (Table 3, Figure 7). This difference was associated with outward signs of distress in GRFi and HSAi cows; however, concentrations of ST increased during the sampling interval in HSAi, but not in GRFi cows (Figure 7). Concentrations of cortisol ( $\mathrm{ng} / \mathrm{ml}$ ) across all days pp were low and similar in GRFi (8.0 \pm 1.5$)$ and in HSAi (7.6 \pm 1.5$)$ cows.

Pulsatile release of ST (Table 3) was not different from zero in GRFi cows on all days pp and was less $(P<.01)$ than the frequency of ST release in HSAi cows. In HSAi cows, frequency of ST release did not vary with days pp. Basal ST was greater in HSAi than in GRFi cows on all days sampled; however, this difference was significant only on days 26 and $50 \mathrm{pp}$, only.

Concentrations of IGF-I in GRFi and HSAi cows are depicted in Figure 8. Serum IGFI was lower in GRFi than in HSAi cows on all days pp.

The opioid agonist, FK33-824, significantly increased ST in HSAi, but not in GRFi cows, on all days pp. Serum ST increased following FK33-824 similarly on all days pp in HSAi cows, thus, concentrations of ST were pooled across days pp (Figure 9). Concentrations of ST were not altered $(P>.2)$ by two injections of naloxone (data not presented).

Consumption of milk by calves was not affected by treatment in Exp. 2. Milk consumption $(\mathrm{kg} / \mathrm{d})$ averaged across days $78,92,106$ and 130 was similar in HSAi (7.2 \pm 1.2$)$ and GRFi $(6.0 \pm 1.2)$ cows. In addition, ADG was similar in calves nursing dams immunized against GRF or HSA (data not shown). 

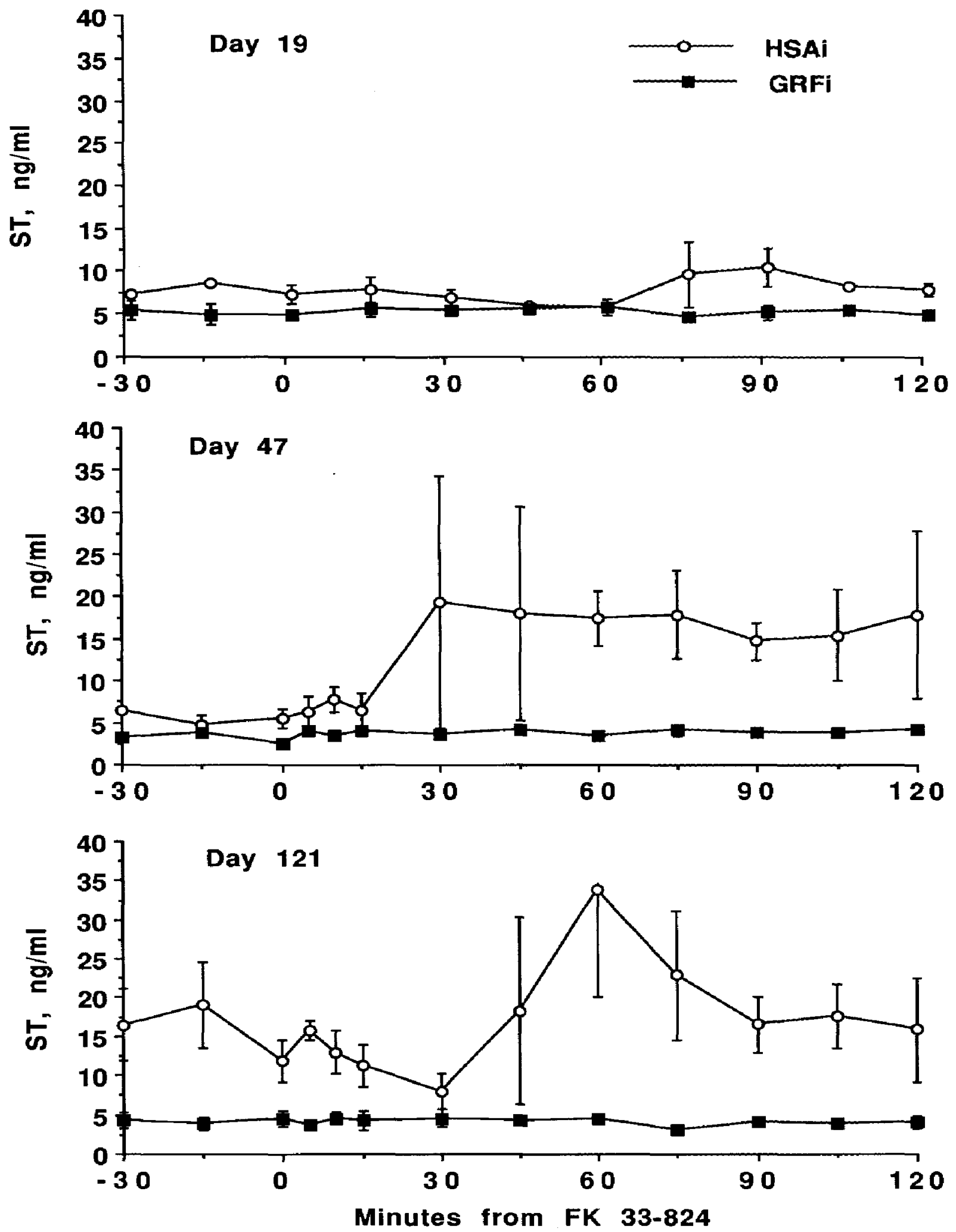

Figure 3. Mean ( \pm SE) ST from -30 to $120 \mathrm{~min}$ from administration (IV) of FK33-824 (opioid agonist, $10 \mu \mathrm{g} / \mathrm{kg} \mathrm{BW}$ ) on days 19,47 and 121 postpartum in cows immunized against GRF conjugated to HSA (GRFi) or HSA (HSAi). Serum ST increased on days 47 and 121 but not on day 19 postpartum in HSA cows only $(P<0.05)$. Serum ST did not increase $(P>0.2)$ after FK33-824 in GRFi cows (Exp. 1). 


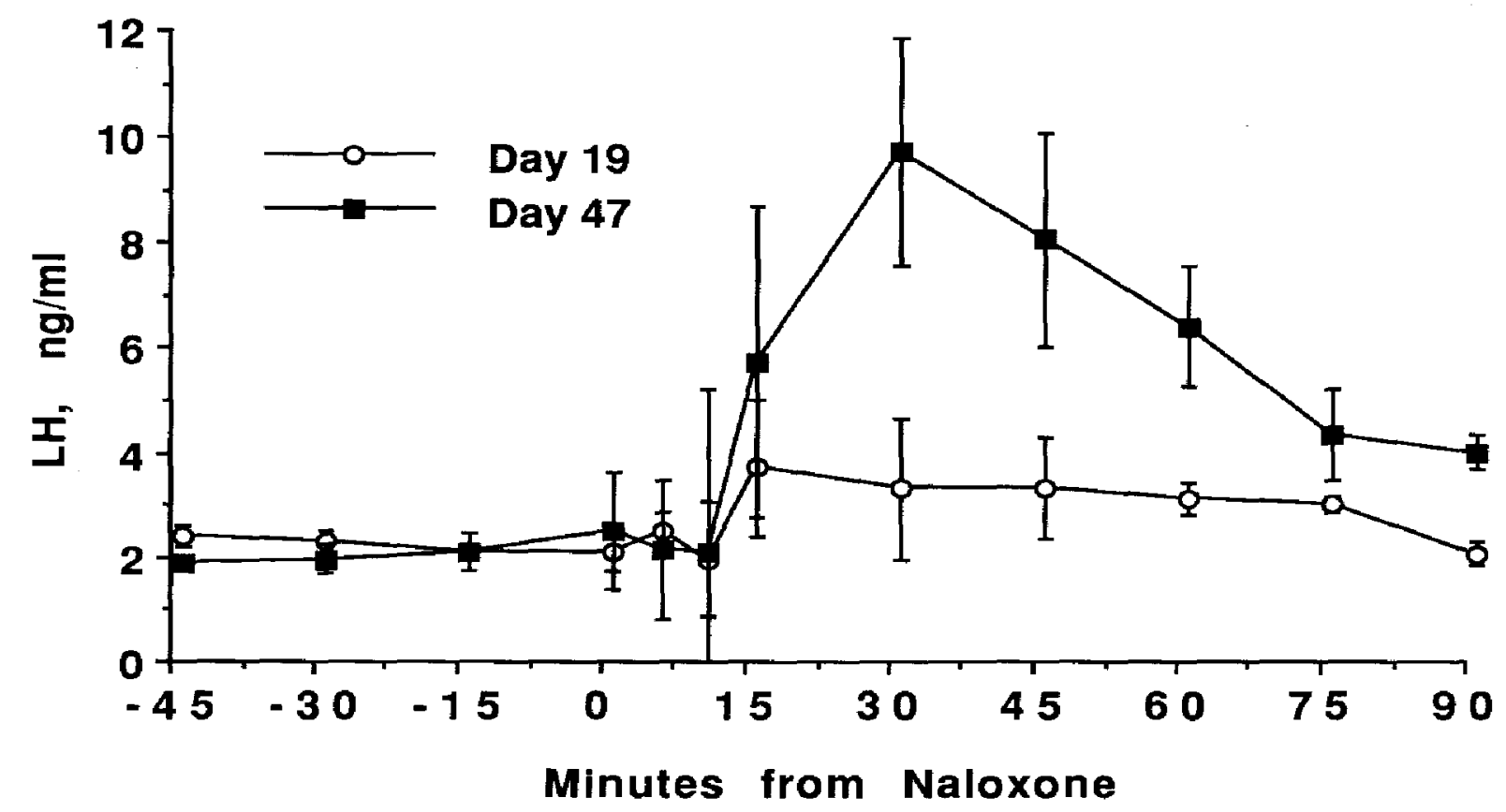

Figure 4. Concentrations of LH (mean $\pm \mathrm{SE}$ ) from -45 to 90 min from administration of naloxone in GRFi and HSAi cows on days 19 and 47 postpartum. Serum LH was similar $(P>0.2)$ in GRFi and HSAi cows, thus data were pooled. Naloxone increased LH on day $47(\mathrm{P}<0.05)$ but not on day 19 postpartum (Exp. 1).

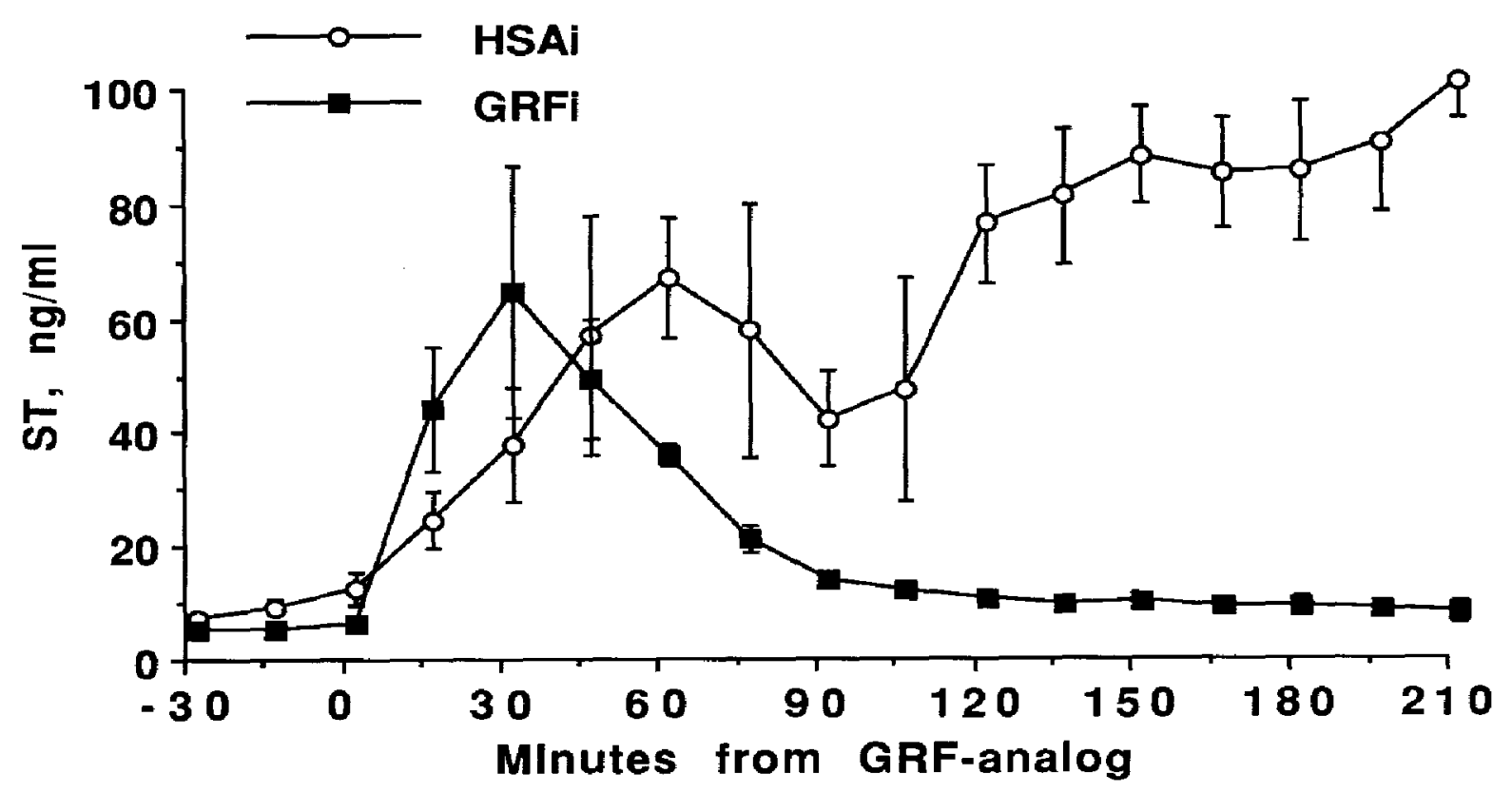

Figure 5. Average ( \pm SE) ST concentrations from -30 to 210 min from administration of a GRF-analog on day 47 postpartum in GRFi and HSAi cows. ST increased $(P<0.05$ ) following GRF-analog in both treatment groups but remained elevated throughout the remainder of the sampling period in HSAi cows only (Exp. 1).

Change in $\mathrm{BW}(\mathrm{kg})$ of cows from -13 to $73 \mathrm{~d}$ pp was similar in GRFi $(-21 \pm 5)$ and HSAi $(-24 \pm 4)$ cows. Interval from calving to ovulation, estimated by elevated progesterone $(>$ $1.0 \mathrm{ng} / \mathrm{ml})$, tended to be greater $(\mathrm{P}<.12)$ in HSAi $(62 \pm 8 \mathrm{~d})$ than in GRFi $(44 \pm 6 \mathrm{~d})$ cows. Analysis across experiment (or year) revealed that treatment, but not experiment or treatment $x$ experiment, contributed $(\mathrm{P}<.05)$ to variation in days from calving to ovulation. Interval from calving to elevated progesterone was lower in GRFi $(48 \pm 4, n=7)$ than in $\mathrm{HSAi}$ $(65 \pm 6, n=9)$ cows. 


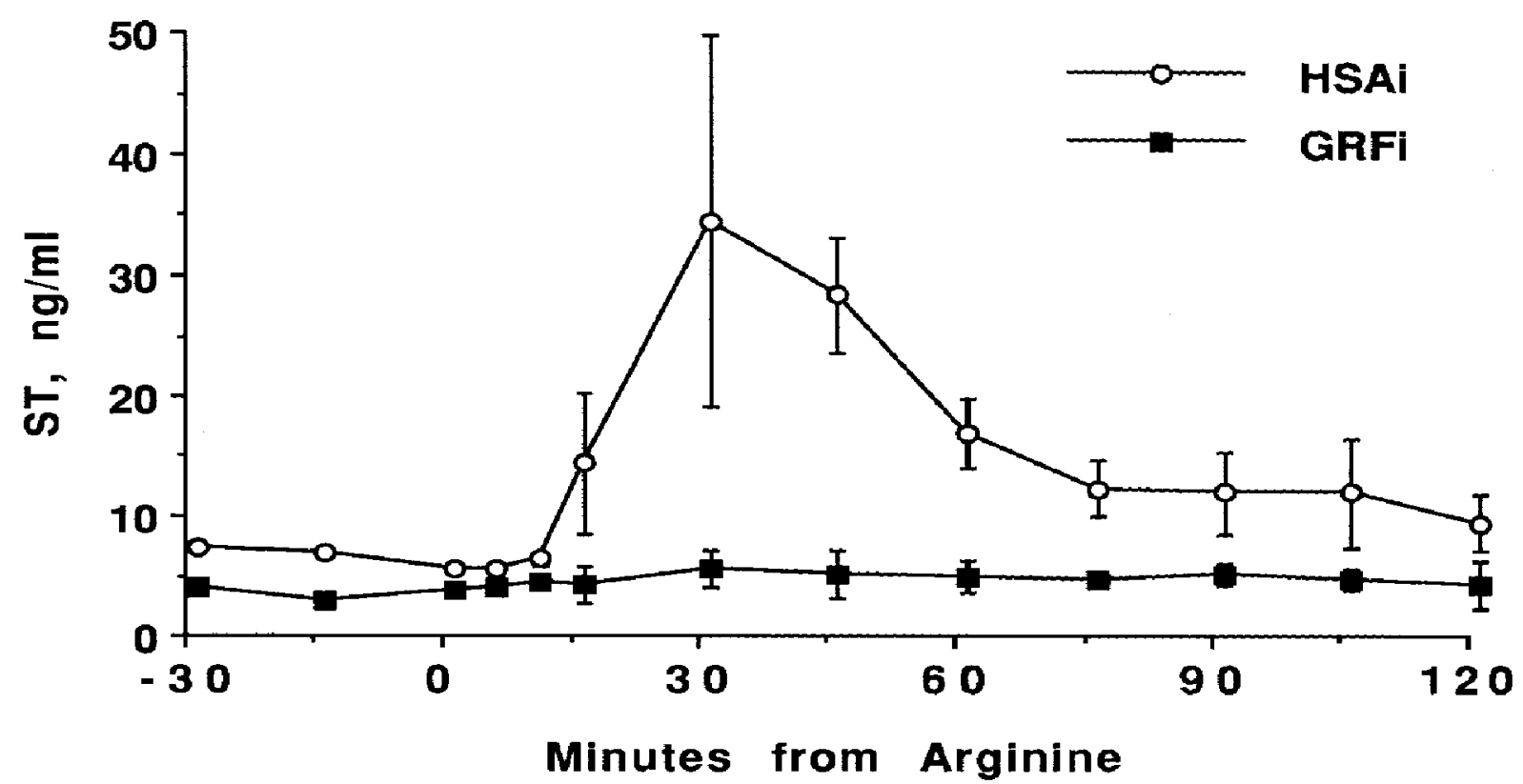

Figure 6. Mean ( \pm SE) ST level on day 121 postpartum from -30 to $120 \mathrm{~min}$ from arginine in cows immunized against GRF conjugated to HSA (GRFi) or HSA (HSAi). Concentrations of ST increased $(P<0.05)$ after arginine in HSAi but not in GRFi cows (Exp. 1).

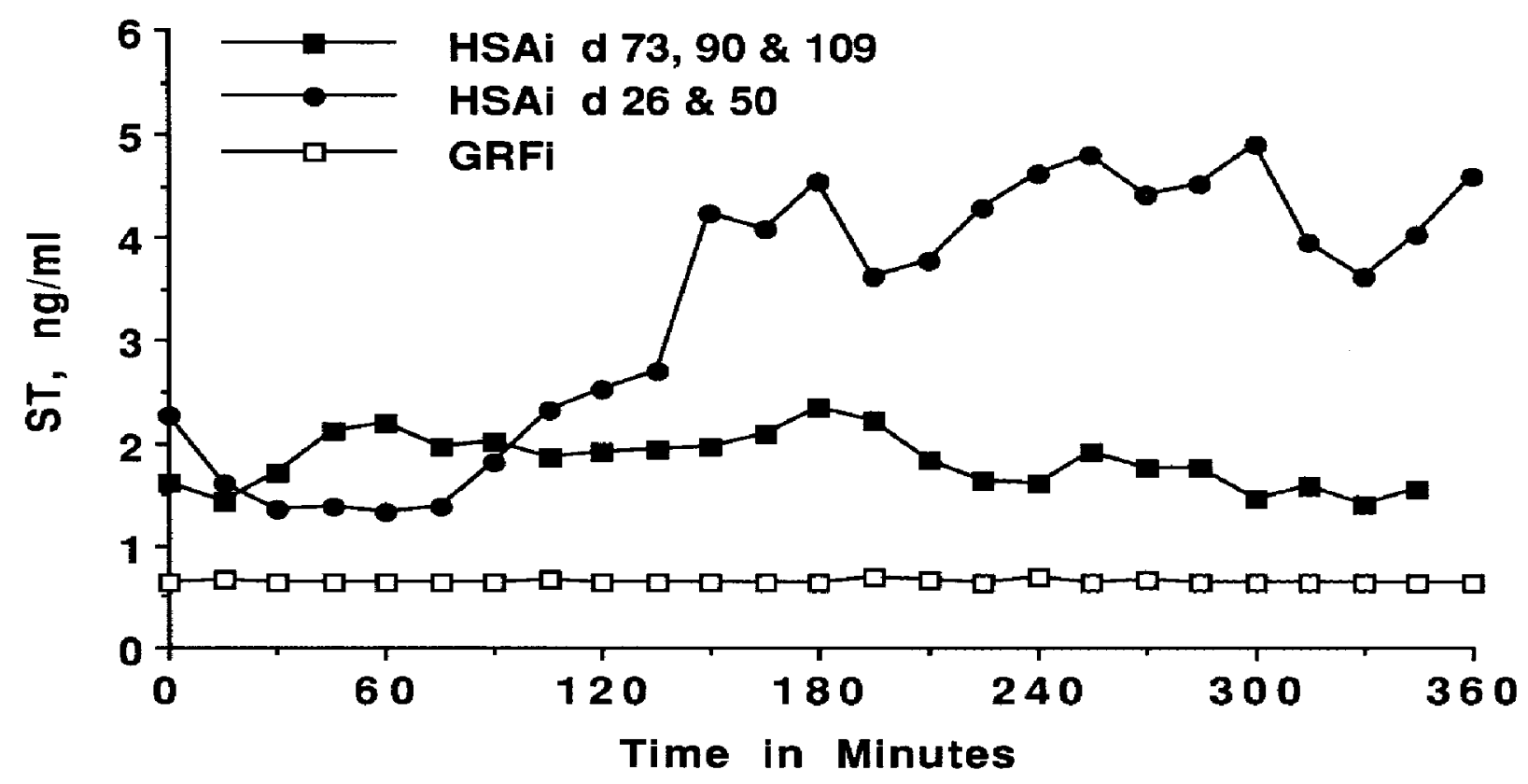

Figure 7. Concentrations of ST on days 26, 50, 73,90 and 109 postpartum in HSAi and GRFi cows. ST was not affected by day postpartum in GRFi cows, thus data were pooled across day. Serum $S T$ was lower $(P<0.05)$ in GRFi than in HSAi on all day postpartum. Serum ST was greater $(P<0.05)$ in HSAi cows on days 26 and 50 than on days 73, 90 and 109 (Exp. 2).

Table 2. Percentage Binding of Serum From Cows Immunized Against GRF conjugated to HSA (GRFI) OR HSA ALONE (HSAI) (EXP. 2).

\begin{tabular}{ccc}
\hline & \multicolumn{2}{c}{ Percentage Binding at 1:1000 Dilution } \\
\cline { 2 - 3 } Days Postpartum & GRFi & HSAi \\
\hline-13 & $0.5 \pm 0.3^{\mathrm{b}}$ & $0.2 \pm 0.2$ \\
$8^{\mathrm{a}}$ & $1.0 \pm 0.7^{\mathrm{c}}$ & $<0.2$ \\
29 & $10.0 \pm 3.6^{\mathrm{c}}$ & $<0.2$ \\
89 & $17.0 \pm 4.7^{\mathrm{c}}$ & $1.4 \pm 0.4$ \\
\hline
\end{tabular}

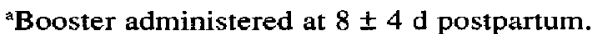

'Mean \pm SE.

${ }^{\mathrm{c}} \mathrm{GRFi}$ vs HSAi, $\mathrm{P}<0.05$. 
Table 3. Effect of Active Immunization Against GRF conjugated to HSA (GRFI) OR HSA ALONE (HSAI) ON ST (EXP. 2)

\begin{tabular}{|c|c|c|}
\hline \multirow[b]{2}{*}{ Day postpartum } & \multicolumn{2}{|c|}{ Treatment } \\
\hline & GRFi & HSAi \\
\hline & \multicolumn{2}{|c|}{ Mean ST (ng/mi) } \\
\hline 26 & $0.6 \pm 0.1^{\mathrm{a}, \mathrm{b}}$ & $3.5 \pm 0.2$ \\
\hline 50 & $0.6 \pm 0.1^{\mathrm{b}}$ & $3.9 \pm 0.3$ \\
\hline 73 & $0.6 \pm 0.1^{b}$ & $2.2 \pm 0.1$ \\
\hline 90 & $0.7 \pm 0.1^{b}$ & $1.9 \pm 0.1$ \\
\hline \multirow[t]{2}{*}{109} & $0.8 \pm 0.1^{b}$ & $1.9 \pm 0.1$ \\
\hline & \multicolumn{2}{|c|}{ ST peaks per $6 \mathrm{hr}$} \\
\hline 26 & $0.0 \pm 0.0^{b}$ & $2.7 \pm 0.1$ \\
\hline 50 & $0.3 \pm 0.3^{b}$ & $3.3 \pm 0.1$ \\
\hline 73 & $0.0 \pm 0.0^{b}$ & $2.7 \pm 0.6$ \\
\hline 90 & $0.3 \pm 0.3^{b}$ & $2.8 \pm 0.4$ \\
\hline \multirow[t]{2}{*}{109} & $0.0 \pm 0.0^{b}$ & $2.3 \pm 0.4$ \\
\hline & \multicolumn{2}{|c|}{ Basal ST (ng/ml) } \\
\hline 26 & $0.6 \pm 0.1^{\mathrm{b}}$ & $1.9 \pm 0.1$ \\
\hline 50 & $0.6 \pm 0.1^{\mathrm{b}}$ & $1.7 \pm 0.1$ \\
\hline 73 & $0.6 \pm 0.1$ & $1.3 \pm 0.1$ \\
\hline 90 & $0.6 \pm 0.1$ & $1.3 \pm 0.3$ \\
\hline 109 & $0.8 \pm 0.1$ & $1.2 \pm 0.2$ \\
\hline
\end{tabular}

Mean \pm SE.

${ }^{\mathrm{b}} \mathrm{GRFi}$ is $\mathrm{HSAi}, \mathrm{P}<0.05$.

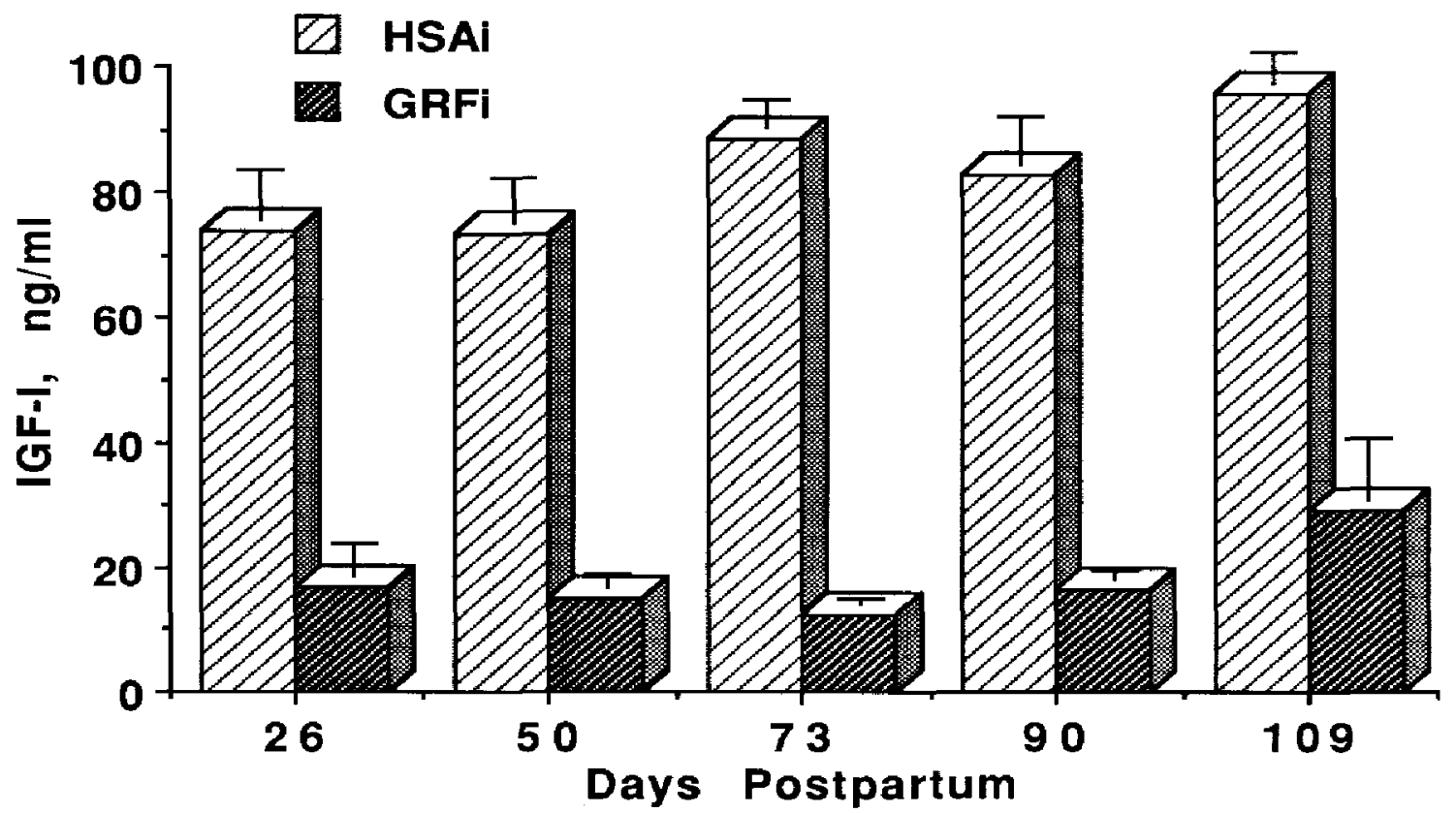

Figure 8. Mean ( \pm SE) IGF-I concentrations in GRFi or HSAi cows. GRFi cows had lower $(P<0.05)$ IGF-I concentrations than HSAi cows (Exp. 2). 


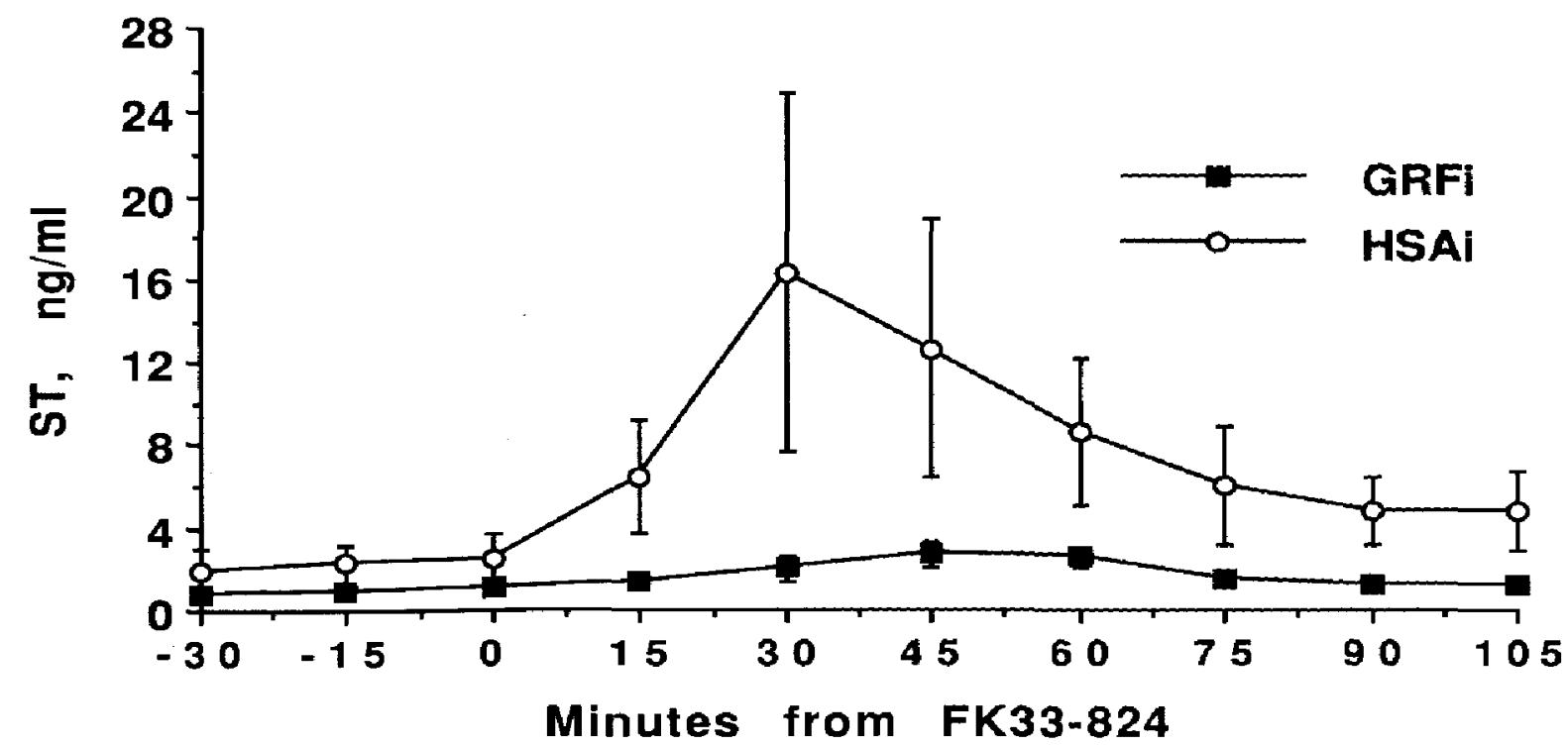

Figure 9. Concentrations of ST ( \pm SE) averaged over days $27,51,91$ and 110 postpartum in $G R F i(n=4$ ) and HSAi ( $n=3$ ) cows from -30 to 105 min post FK33-824 injection. Within treatment, change in ST following FK33-824 was similar across days postpartum, thus data were pooled. Concentrations of ST increased $(P<0.05)$ in HSAi cows but not in GRFi cows after FK33824 (Exp. 2).

\section{DISCUSSION}

Lactating beef cows were successfully immunized against GRF as evidenced by the presence of GRF antibodies, absence of pulsatile release of ST, decreased serum IGF-I and the failure of an opioid agonist or arginine to increase ST in cows immunized against GRF. Similar results were observed with passive immunization against GRF in rats $(29,30)$ and active immunization against GRF in pigs (15), steers (31) and heifers (16). Results from Exp. 2 reveal that one booster following a primary immunization is sufficient to suppress pulsatile ST and circulating IGF-I through $100 \mathrm{~d}$ postpartum.

In both experiments, antibody binding did not achieve $50 \%$ at any assay dilution. In contrast, prepubertal beef heifers (16) and gilts (15) actively immunized against GRF achieved titers (dilutions required to bind $50 \%$ of radiolabeled-GRF) ranging from 1:11,000 to > 1:60,000. Antibody binding in Exp. 1 and 2 was sufficient to abolish episodic release of ST in all GRF-immunized cows. Two GRF-immunized cows in Experiment 2 displaying pulsatile release of ST had binding of $10 \%$ or less at a 1:1000 dilution, thus data were omitted from other analyses. The seven remaining GRFi cows with abolished episodic release of ST (Exp. 1 and 2) had antibody binding ranging from 10\% to 35\% at either a 1:100 or 1:1000 dilution.

Immunoneutralization of GRF decreased mean ST concentrations by obliterating pulsatile release of ST and decreasing basal ST. Techniques used to study the role of GRF regulation on ST secretion such as hypothalamic deafferentation (32), hypothalamic ventromedial lesions (33) or hypophyseal stalk transection $(34,35)$ have demonstrated similar decreases in ST episodic secretion. However, basal concentrations of ST in Klindt and coworkers study (35) were elevated after hypophyseal stalk transection possibly due to a decreased amount of somatostatin reaching the pituitary gland.

Serum concentrations of ST were lower in GRF-immunized cows, primarily due to a lack of pulsatile release of ST, and this was associated with lower concentrations of IGF-I in both experiments. Hypophysectomy in pigs (36) and active immunization against GRF in heifers (16), steers (31) and pigs (15) were also associated with decreased serum IGF-I. Hannon et al. (37) recently reported that liver IGF-I mRNA and liver IGF-I production were significantly correlated with amplitude of ST release in beef cattle. 
Administration of a GRF-analog increased ST in GRF- and HSA-immunized cows in Experiment 1. Cows immunized against HSA alone maintained elevated ST concentrations for the duration of blood sampling (210 minutes post GRF-analog) similar to that in previous reports utilizing GRF(1-29)- $\mathrm{NH}_{2}$ in heifers and pigs $(38,39)$. However, the response observed in GRFi cows was abrupt and short-lived when compared to HSAi (control) cows. In contrast to our results, Armstrong et al (15) and Simpson et al (16) observed that antibodies against GRF cross-reacted with GRF analog as evidenced by the inability of the GRF analog to stimulate ST in pigs pr heifers immunized against GRF. The discrepancy between results of the present study and the aforementioned studies $(15,16)$ is likely related to the greater antibody levels. Comparing the present results with Armstrong et al (15), different antibody epitopes are not indicated, as both cow and pig antibodies similarly bind [ ${ }^{125}$ I] GRF-analog (R. M. Campbell, unpublished observation).

Infusion of arginine increased ST concentrations in HSAi but not in GRFi cows (Experiment 1). Arginine has been shown to elevate ST levels in sheep (40), cows (41) and pigs (42). Since GRFi cows did not respond to arginine, it would seem that the mechanism of action of arginine-induced ST secretion involves release of hypothalamic GRF. This is in agreement with Anderson et al (42); they reported that stalk transection blocked the stimulatory effect of arginine on ST in pigs. However, in vitro studies using rat pituitary cells indicated that arginine administration stimulated ST release by inhibiting somatostatin release from the hypothalamus (43). Thus, a synergistic effect of arginine involving GRF and somatostatin cannot be excluded.

Based on the consistency of these results, it appears that opioid peptides stimulate ST in the cow through stimulation of GRF. Administration of an opioid agonist, FK33-824, failed to increase ST in GRFi cows, whereas injection of FK33-824 in HSAi cows was followed by an episode of ST release on all days postpartum except for day $19 \pm 1$ pp in Exp. 1. Passive immunization against GRF abolished increases of ST following $\beta$-endorphin (44), morphine (30) or FK33-824 (45). Active immunization against GRF in pigs (15) or heifers (16) had similar results. Also, a stimulatory effect of opioid peptide agonists on ST has been demonstrated in rodents (46), sheep (14) and heifers $(13,16)$.

We were surprised that administration of naloxone, an opioid antagonist, did not decrease concentrations of ST in either GRFi or HSAi cows on any day postpartum in Exp. 1 or 2. Other reports have demonstrated that naloxone decreased ST in the suckled rat (47) and pig (7). Naloxone was apparently present in sufficient quantities on day 47 (Exp. 1) to interact with opioid receptors, because naloxone increased LH in all heifers on day 47 . The dosage of naloxone may have been inadequate to decrease ST on day 19 because concentrations of LH failed to increase after naloxone and ST failed to increase after FK33-824 on day 19. Similar increases in LH after naloxone were reported for postpartum women (48) and postpartum beef cows (9). Whisnant and coworkers (9) observed that challenges of naloxone stimulated LH release on days 28 and 42, but not on day 14 postpartum. We cannot explain why naloxone increased LH but failed to decrease serum concentrations of ST on day 47 , but previous reports have demonstrated that opioid receptor agonists such as FK33-824 bind preferentially but not exclusively to mu receptors rather than the native enkephalin delta receptors (49). The existence of various opioid binding sites may provide a logical assumption for differences seen in endocrine responses to naloxone. Therefore in the lactating cow, a larger dose and(or) infusion of naloxone may be required for blockage of the opioid receptor regulating GRF secretion so that attenuation of ST can be observed.

The failure of FK33-824 to increase ST and that of naloxone to increase LH on day 19 pp, whereas similar treatments on day 47 pp increased ST and LH, indicates a change in opioid sensitivity may have occurred between days 19 and 47 postpartum. This change in sensitivity in ST in response to FK33-824 was not observed, however, in Exp. 2. Several differences between Exp. 1 and 2 (location, year, diet - hay vs silage, breed) render this 
question unanswerable. However, it is interesting to note that serum IGF-I concentrations were affected by day pp in Exp. 1 but not in Exp. 2.

Apparent distress associated with sampling in Exp. 2 coincided with elevated concentrations of ST. Cortisol levels, however, were low and not different between treatment groups.

Milk consumption by calves and cow weight loss were apparently affected by treatment in Exp. 1, but not Exp. 2. The effect of treatment on milk consumption was transient in Exp. 1 particularly since ADG of calves was not altered. A decrease in milk yield and, thus a decrease in energy necessary for milk synthesis, is consistent with the homeorrhetic effects of ST in ruminants $(3,50,51)$.

Immunization against GRF tended to hasten onset of ovulation in Exp. 1 and 2. In Exp. 1 only, this difference was associated with differences in cow BW change. As reviewed by Randel (52) and Short (53), cows losing less weight postpartum would be expected to have an earlier resumption of estrous cycles. However, in both Exp. 1 and 2 serum IGF-I was lower in GRFi than in HSAi cows. This is in contrast to studies by Simpson in that primiparous cows (54) and heifers (16) with lower serum IGF-I had greater intervals from calving to elevated progesterone (54) and age at puberty (16). Additional studies are needed to clarify the relationship among metabolism, serum IGF-I and ovarian function.

We cannot explain why GRFi altered milk consumption of calves and cow weight change in Exp. 1 but not in Exp. 2. However, several explanations are possible. In addition to differences in breed, year and location, a major difference was that cows in Exp. 2 were restricted in feed intake. As expected, cow weight change was greater in Exp. 2 than in 1. It is possible that the homeorrhetic effects of ST vary with nutritional status of the cow. Additional studies are necessary to investigate this possibility.

In conclusion, gestating-lactating beef cows were successfully immunized against growth hormone-releasing factor as measured by presence of antibodies against GRF, abolishment of episodic release of ST and suppressed concentrations of IGF-I. Failure of a GRF analog, an opioid agonist and arginine to stimulate ST verified the completeness of the immunoneutralization and provide strong evidence that opioid peptides and arginine increase serum ST through a mechanism primarily involving GRF. Immunoneutralization against GRF provides an effective model to evaluate factors regulating ST in the cow.

\section{ACKNOWLEDGEMENTS/FOOTNOTES}

This research was supported by North Carolina ARS. Use of trade names in this publication does not imply endorsement by the North Carolina ARS, nor criticism of similar products not mentioned. Purified ovine GH and antiserum were provided by A. F. Parlow, Torrance, CA; human IGF-I antiserum through the National Hormone and Pituitary Program, NIDDK and Univ, of Maryland, School of Medicine, Baltimore, MD; FK33824 by Sandoz Pharmaceuticals Corp., East Hanover, NJ; naloxone by DuPont Pharmaceuticals, Wilmington, DE. Appreciation is expressed to D. Askew, M. Galloway, H. Tyler, E. Jones, C. Marsh, Jr. and P. Stricker for technical assistance.

Reprint requests should be forwarded to J.D. Armstrong.

\section{REFERENCES}

1. Tucker HA, Merkel RA. Applications of hormones in the metabolic regulation of growth and lactation in ruminants. Fed Proc 46:300-306, 1987.

2. Trenkle A, Topel DG. Relationships of some endocrine measurements to growth and carcass composition of cattle. J Anim Sci 46:1604-1609, 1978.

3. Bauman DE, Eppard PJ, DeGeeter MJ, Lanza GM. Responses of high-producing dairy cows to long-term treatment with pituitary somatotropin and recombinant somatotropin. J Dairy Sci 68:1352-1362, 1985.

4. Eisemann JH, Hammond AC, Rumsey TS, Bauman DE. Nitrogen and protein metabolism and metabolites in plasma and urine of beef steers treated with somatotropin. J Anim Sci 69:105-115, 1989.

5. Armstrong JD, Kraeling RR, Britt JH. Effects of naloxone or transient weaning on secretion of LH and prolactin in lactating sows. J Reprod Fertil 83:301-308, 1988.

6. Armstrong JD, Kraeling RR, Britt JH. Morphine suppresses luteinizing hormone concentrations in transiently weaned sows and delays onset of estrus after weaning. J Anim Sci 66:2216-2223, 1988.

7. Armstrong JD, Esbenshade KL, Coffey MT, Heimer E, Campbell R, Mowles T, Felix A. Opioid control 
of growth hormone in the suckled sow is primarily mediated through growth hormone releasing factor. Domest Anim Endocrinol 7:191-198, 1990.

8. Whisnant CS, Kiser TE, Thompson FN, Barb CR. Influence of calf removal on the serum luteinizing hormone response to naloxone in the postpartum cows. J Anim Sci 63:561-564, 1986.

9. Whisnant CS, Thompson FN, Kiser TE, Barb CR. Effect of naloxone on serum luteinizing hormone, cortisol and prolactin concentrations in anestrous beef cows. J Anim Sci 62:1340-1345, 1986.

10. Guilleman R, Brazeau P, Bohlen P, Esch F, Ling N, Wehrenberg WB. Growth hormone-releasing factor from human pancreatic tumor that caused acromegaly. Science 218:585-587, 1982.

11. Brazcau P, Bohlen P, Esch F, Ling N, Wehrenberg W, Guilleman R. Growth hormone-releasing factor from ovine and caprine hypothalamus: isolation, sequence analysis and total synthesis. Biochem Biophys Res Commun 125:606-614, 1984.

12. Brazeau P, Vale W, Burgus R, Ling N, Butcher M, Rivier J, Guillemin R. Hypothalamic polypeptide that inhibits the secretion of immunoreactive pituitary growth hormone. Science 179:77-79, 1973.

13. Armstrong JD, Johnson BH. Agonists of endogenous opioid peptides supress LH, and stimulate cortisol and growth hormone during follicular phase in heifers. J Endocrinol 121:11-17, 1989.

14. Armstrong JD, Spears JW. Changes in growth hormone and luteinizing hormone following acute or chronic administration of an opioid agonist, FK33-824, in wethers. J Anim Sci 69:774-781, 1991.

15. Armstrong JD, Esbenshade KL, Johnson JL, Coffey MT, Heimer E, Campbell RM, Mowles T, Felix A. Active immunization of pigs against growth hormone-releasing factor: Effect on concentrations of growth hormone and insulin-like growth factor 1. J Anim Sci 68:427-434, 1990.

16. Simpson RB, Armstrong, JD, Harvey RW, Miller DC, Heimer EP, Campbell RM. Effect of active immunization against growth hormone-releasing factor on growth and onset of puberty in beef heifers. $J$ Anim Sci 69:4914-4924, 1991.

17. Green N, Alexander H, Olson A, Alexander S, Shinnick TM, Suteliffe JG, Lerner RA. Immunogenic structure of the influenza virus hemagglutinin. Cell 28:477-487, 1982.

18. Roemer D, Buescher HH, Hill RC, Pless J, Cardinanx F, Closse A, Hauser D, Hugenin R. A synthetic enkephalin analogue with prolonged parenteral and oral analesgic activity. Nature 268:547-549, 1977.

19. Felix AM, Heimer EP, Mowles TF, Eiseinbeis H, Leung T, Lambros TJ, Ahmed M, Wang CT, Brazeau P. In: Synthesis and biological activity of novel growth hormone releasing factor analog, In: Proc 19th Eur Pept Symp, Chalkidiki, Greece, p. 481, 1986.

20. Mowles T, Stricker P, Eisenbeis H, Heimer E, Felix A, Brazeau P. Effects of novel GRF analog on GH secretion in vitro and in vivo. Endocrinol Jpn 34: (Suppl) 138, 1987.

21. Breier $\mathrm{BH}$, Gluckman PD. The regulation of postnatal growth: nutritional influences on endocrine pathways and function of the somatotrophic axis. Livestock Prod Sci 27:77-94, 1991

22. NRC. Nutrient Requirements of Beef Cattle, National Academy Press, Washington, DC, 1984.

23. Armstrong JD, Spears JW. Intravenous administration of ionophores in ruminants: effects on metabolism independent of the rumen. J Anim Sci 66:1807-1817, 1988.

24. Barnes MA, Boockfor FR, Bierley ST, Kazmer GW, Halman RD, Dickey JF. Effect of unilateral castration and unilateral cryptorchidism on gonadotropin and testosterone response to gonadotropin releasing hormone in the bull. J Anim Sci 53:1341-1350, 1981.

25. Houseknccht KL, Boggs DL, Campion DR, Sartin JL, Kiser TE, Rampacek GB, Amos HE. Effect of dietary energy source and level on serum growth hormone, insulin-like growth factor 1, growth and body composition in beef heifers. J Anim Sci 66:2916-2923, 1988.

26. Holland MD, Hossner KL, Niswender GD, Elsasser TH, Odde KG. Validation of heterologous radioimmunoassay for insulin-like growth factor-I in bovine serum. J Endocrinol 119:281-285, 1988.

27. Jones EJ, Armstrong JD, Harvey RW. Changes in metabolites, metabolic hormones and luteinizing hormone prior to puberty in Angus,Braford, Charolais and Simmental heifers. J Anim Sci 69:1607-1615, 1991.

28. SAS. SAS/STAT Guide for Personal Computers, Version 6 Edition, SAS Institute Inc., Cary, NC, 1985.

29. Wehrenberg WB, Brazeau P, Luben R, Bohlen P, Guilleman R. Inhibition of the pulsatile secretion of growth hormone by monocional antibodies to the hypothalamic growth hormone releasing factor (GRF). Endocrinology 111:2147-2148, 1982.

30. Wehrenberg WB, Brazeau P, Luben R, Ling N, Guillemin R. A noninvasive functional lesion of the hypothalamo-pituitary axis for the study of growth hormone-releasing factor. Neuroendocrinology 36:489 $491,1983$.

31. Trout WE, Schanbacher BD. Growth hormone and insulin-like growth factor-I responses in steers actively immunized against somatostatin or growth hormone-releasing factor. J Endocrinol 125:123-129, 1990.

32. Molina JR, Klindt J, Ford JJ, Anderson LL. Growth hormone and prolactin secretion after hypothalamic deafferentation in pigs. Proc Soc Exp Biol Med 183:163-168, 1986. 
33. Martin JB, Renaud LP, Brazeau P. Pulsatile growth hormone secretion: Suppression by hypothalamic ventromedial lesions and by long-acting somatostatin. Science 186:538-540, 1974.

34. Anderson LL. Development in calves and heifers after hypophysial stalk transection or hypophysectomy. Am J Physiol 232:E497-503, 1977.

35. Klindt J, Ford JJ, Berardinelli JG, Anderson LL. Growth hormone secretion after hypophyseal stalk transection in pigs. Proc Soc Exp Biol Med 172:508-513, 1983.

36. Buonomo FC, Lauterio TJ, Baile CA, Campion DR. Determination of insulin-like growth factor 1 (IGF1) and IGF binding protein levels in swine. Domest Anim Endocrinol 4:23-31, 1987.

37. Hannon K, Gronowski A, Trenkle A. Relationship of liver and skeletal muscle IGF-1 messenger RNA to plasma GH profile, production of IGF-1 by liver, plasma IGF-1 concentrations, and growth rates of cattle. Proc Soc Exp Biol Med 196:155-163, 1991.

38. Petitclerc D, Pelletier G, Lapierre H, Gaudreau P, Couture Y, Dubreuil P, Morisset J, Brazeau P. Dose response of two synthetic human growth hormone-releasing factors on growth hormone release in heifers and pigs. J Anim Sci 65:996-1005, 1987.

39. Dubreuil P, Pelletier G, Petitclerc D, Couture Y, Gaudreau P, Morisset J, Brazeau P. Influence of growth hormone-releasing factor and(or) thyrotropin-releasing factor on somatotropin, prolactin, triiodothyronine and thyroxine release in growing pigs. Can J Anim Sci 68:699-709, 1988.

40. Davis SL. Plasma levels of prolactin, growth hormone and insulin in sheep following the infusion of arginine, leucine and phenylalanine. Endocrinology 91:549-555, 1972.

41. Chew BP, Eisenman JR, Tanaka TS. Arginine infusion stimulates prolactin, growth hormone, insulin and subsequent lactation in pregnant dairy cows. J Dairy Sci 67:2507-2518, 1984.

42. Anderson, LL, Ford JJ, Klindt J, Molina JR, Vale WW, and Rivier J. Growth hormone and prolactin secretion in hypophysial stalk-transected pigs as affected by growth hormone and prolactin-releasing and inhibiting factors. Proc Soc Exp Biol Med 196:194-202, 1991.

43. Alba-Roth J, Muller OA, Schopohl J, von Werder K. Arginine stimulates growth hormone secretion by suppressing endogenous somatostatin secretion. J Clin Endocrinol Metab 67:1186-1189, 1988.

44. Wehrenberg WB, Bloch B, Ling N. Pituitary secretion of growth hormone in response to opioid peptides and opiates is mediated through growth hormone-releasing factor. Neuroendocrinology 41:13-16, 1985 .

45. Murakami $Y$, Kato $Y$, Kabayama $Y$, Inoue $T$, Tojo K, Ohta H, Imura H. Inhibition by antiserun to rat growth hormone-releasing factor of growth hormone secretion induced by a met-enkephalin analog, FK33824, in rats. Proc Soc Exp Biol Med 178:151-154, 1985.

46. Shaar CJ, Clemens JA. The effects of opiate agonists on growth hormone and prolactin release in rats. Fed Proc 39:2539-2543, 1980.

47. Miki N, Sonntag WE, Forman LJ, Meites J. Suppression by naloxone of the rise in plasma growth hormone and prolactin induced by suckling. Proc Soc Exp Biol Med 168:330-333, 1981.

48. Yen S.S.C. Opiates and Reproduction: Studies in women, Raven Press, New York, NY., 1984.

49. Kosterlitz HW, Lord JAH, Paterson SJ, Waterfield AA. Effects of changes in the structure of enkephalins and of narcotic analgesic drugs on their interaction with mu and delta receptors. Br J Pharmacol 680:333$342,1980$.

50. Bauman BE, Currie WB. Partitioning of nutrients during pregnancy and lactation: A review of mechanisms involving homeostasis and homeorhesis. J Dairy Sci 63:1514-1529, 1980.

51. Breier GH, Gluckman PD, McCutcheon SN, Davis SR. Physiological responses to somatotropin in the ruminant. J Dairy Sci 74 [Suppl 1]:20-34, 1991.

52. Randel RD. Nutrition and postpartum rebreeding in cattle. J Anim Sci 68:853 $862,1990$.

53. Short, RE, Bellows RA, Staigmiller RB, Berardinelli JG, Custer EE. Physiological mechanisms controlling anestrus and infertility in postpartum beef cattle. J Anim Sci 68:799-816, 1990.

54. Simpson, RB, Armstrong JD, Harvey RW. Effect of prepartum administration of growth hormone releasing factor on somatotropin, insulin-like growth factor I, milk production and postpartum return to ovarian activity in primiparous beef heifers. J Anim Sci 70: 1478-1487, 1992. 